\title{
Psychometric Properties of the Spanish Version of the Flow State Scale
}

\author{
Tomás García Calvo ${ }^{1}$, Ruth Jiménez Castueraㄹ, Francisco Javier Santos-Rosa Ruano², \\ Raúl Reina Vaíllo ${ }^{3}$, and Eduardo Cervelló Gimeno ${ }^{3}$ \\ ${ }^{1}$ Universidad de Extremadura (Spain) \\ ${ }^{2}$ Universidad de Sevilla (Spain) \\ ${ }^{3}$ Universidad Miguel Hernandez (Spain)
}

\begin{abstract}
The purpose of this research was to examine the psychometric properties of a Spanish translation of the Flow State Scale (FSS; Jackson \& Marsh, 1996). This instrument is used to assess the Flow State in participants of physical activity, although it can be adapted to other contexts (such as work, educational contexts, etc.). This construct can be considered the optimal psychological state to carry out an activity, being closely related to motivation and personal enjoyment (Csikszentmihalyi, 1997). A sample of 2036 athletes was recruited from diverse sports activities. The results revealed satisfactory validity and internal consistency of the instrument, obtaining a factor model made up of a main factor and nine subscales. The correlations between motivational orientations and the flow state are highlighted. The Spanish translation of this instrument is found to be acceptable, with similar psychometric properties as the original scale, although future research in other contexts is needed to support these outcomes.
\end{abstract}

Keywords: Flow State Scale, psychometric properties, motivation

\begin{abstract}
El objetivo de esta investigación fue analizar las propiedades psicométricas de una versión adaptada al castellano de la Flow State Scale (FSS; Jackson y Marsh, 1996), instrumento utilizado para valorar el estado de fluidez en practicantes de actividad física, aunque adaptable a otros contextos (trabajo, educación...). Dicho constructo puede ser considerado como el estado psicológico óptimo para realizar una actividad, estando muy relacionado con la motivación y el disfrute personal (Csikszentmihalyi, 1997). Se desarrolló un estudio con 2036 participantes en diferentes actividades deportivas. Los resultados han demostrado que el instrumento posee una validez y consistencia interna aceptables, hallándose un modelo factorial compuesto por un factor principal y nueve factores secundarios. Asimismo, destacan las correlaciones entre las dos orientaciones motivacionales y el estado de fluidez. Se concluye que la adaptación al castellano del instrumento para valorar el estado de fluidez es aceptable, encontrándose propiedades psicométricas similares a las obtenidas en la escala original, aunque se necesitan nuevos trabajos en otros contextos que apoyen estos resultados.
\end{abstract}

Palabras clave: Escala de Estado de Fluidez, propiedades psicométricas, motivación

Correspondence concerning this article should be addressed to Tomás García Calvo, Facultad de Ciencias del Deporte, Universidad de Extremadura, Avda /Universidad s/n, 10071- Cáceres (SPAIN). E-mail: tgarciac@unex.es

Translation: Virginia Navascués Howard

How to cite the authors of this article: García Calvo, T., Jiménez, R., Santos-Rosa Ruano, F.J., Reina, R. and Cervelló, E. 
A large amount of investigations and studies developed over the last few years in psychology focus on discovering and analyzing the variables that may impair performance and satisfaction when carrying out an activity, in an attempt to determine negative experiences during performance (Craft, Magyar, Becker, \& Feltz, 2003; Smith, Smoll, Cumming, \& Grossbard, 2006). However, few works have attempted to determine which cognitive processes may contribute to improving performance, satisfaction, and wellbeing through optimal subjective experiences. In this vein, various recent works attempt to confirm the factors that are associated with an appropriate psychological state for the promotion of labor and leisure activities, many of them focused on the sport context (see Jackson \& Csikszentmihalyi, 1999).

Hence, the proliferation of efforts to increase our knowledge of these dimensions through qualitative and quantitative investigations, starting from the proposal of Csikszentmihalyi (1975), who considered a flow state to be the optimal psychological state to perform an activity. Privette and Bundrick (1987, p. 316) refer to the flow state as "an intrinsically enjoyable experience, ... is similar to both peak experience and peak performance.....Flow per se does not imply optimal joy or performance but may include either or both."

Along these lines, Csikszentmihalyi and LeFevre (1989) state that when this occurs, individuals feel they can improve their capacity to face the challenge. This involves improving their skills and the possibility of learning new actions that will contribute to increasing their capacity and optimizing their self-esteem and self-confidence.

Mundell (2000) established the concept of flow as a state of deep concentration, perceived control, loss of selfawareness, and distortion of the sense of time. Therefore, the flow state can be considered to be associated with an optimal psychological state that allows one to carry out activities in ideal conditions, optimizing satisfaction and performance (Jackson \& Eklund, 2002).

To obtain more information about this construct with qualitative investigations, Jackson $(1993,1996)$ attempted to determine the elements that constitute the flow state in sports. Thus, on the basis of Csikszentmihalyi's (1990) theoretical proposal, he discovered that most sportspeople explain the flow state by means of nine factors that usually are directly related to the experience of the optimal psychological state and that we shall explain below.

1. Balance between ability level and challenge. To consider that the task to be performed involves an achievable challenge will improve the individual's motivation to perform it and, naturally, to consider that one has the skill to overcome the challenge will help one to find an optimal psychological state.

2. Merging of action and awareness. This characteristic focuses on performing tasks automatically. This automaticity leads one to perform the activity more fluidly, thus avoiding the emergence of intrusive thoughts.
3. Clear goals. Many authors have expressed the importance of having clear goals in order to optimize the performance of an activity at the psychological level (see Roberts, 2001).

4. Direct and clear feedback. When performing a task, it is essential to know if one is doing it correctly, as this will lead to achieving an optimal state.

5. Concentration on the task being performed. To be absolutely concentrated on the task is an essential characteristic to explain an optimal state in sport participation (Cervelló, Santos-Rosa, Jiménez, García Calvo, \& Iglesias, 2007).

6. Sense of control. This dimension refers to sportspeople's feeling that they control and master the task they are facing.

7. Loss of self-consciousness or inhibition. This is the capacity to avoid concerns and worries about one's own skill. This helps sportspeople feel more daring when facing the task.

8. Distortion of the sense of time. The practitioners' sense of time is altered depending on their interests: in some cases, there is a reduced sense of time and, in others, an increased sense of time. This enhances a more positive psychological attitude and, in turn, leads to better task performance.

9. Autothelic experience. This characteristic refers to the intrinsic satisfaction produced by the task. This is related to the self-determination theory (Ryan \& Deci, 2002), which postulates that a task is easier to perform when one feels satisfaction simply from doing it, without the need of any external reward.

Many studies have attempted to assess the characteristics that may affect the sense of flow state, developing instruments for this purpose (Csikszentmihalyi \& Csikszentmihalyi, 1988; Csikszentmihalyi \& Larson, 1987; Csikszentmihalyi \& LeFevre, 1989; Ellis, Voelk1, \& Morris, 1994; Ghani \& Deshpande, 1994; Kimiecik \& Stein, 1992; Webster, Trevino, \& Ryan, 1993). These studies found a series of limitations and difficulties to develop valid and reliable measurements. One of the main limitations of these investigations is that antecedents, consequences, and promoters of flow state were not clearly distinguished, so the measurements created and used for this purpose were theoretically deficient.

One of the first instruments is the Experience Sampling Method, validated among others by Csikszentmihalyi and Larson (1987). This method consists of asking the participants questions, at different times of the day during a defined time interval, about the emergence of positive experiences and their relation with the flow state. Specifically, participants responded to a measurement instrument that had open and closed questions, and they also had to report the times and situations in which they achieved an optimal psychological state. The main disadvantages of this tool are the difficulty to analyze its psychometric properties and its cost, in terms of time, both for the participants and investigators (Kimiciek \& Jackson, 2002). 
Trevino and Webster (1992) used four items to measure flow. These four items were related to control, focus of attention, curiosity, and intrinsic motivation. In 1993, Webster, Trevino, and Ryan further developed this questionnaire, extending the number of items to 12 , although they maintained the four factors. Despite the validation of this tool and its usefulness to collect information about certain aspects, it cannot be considered a measurement of flow state because it does not match the theoretical factors that constitute this variable (Kimiecik \& Jackson, 2002).

Due to the deficiencies observed in the instruments developed, Jackson and Marsh created a tool including the nine factors that correspond to the flow state. Thus, the Flow State Scale (FSS; Jackson \& Marsh, 1996) appeared: a 36item tool, with 4 items for each one of the nine dimensions that comprise the flow state. Responses to this instrument are rated on a 5-point Likert-type scale.

The FSS has been validated in diverse studies and investigations, such as those of Jackson and Marsh (1996), Marsh and Jackson (1999), and Tenenbaum, Fogarty, and Jackson (1999) with American and Australian populations, or those carried out by Doganis, Iosifidou, and Vlachopoulos (2000) and Stavrou and Zervas (2004) with Greek populations. In all these works, the questionnaire presented acceptable validity and internal consistency, with a similar factor structure, and two models emerged that have acceptable fit indexes. These models are the hierarchical confirmatory model, with a principal factor and nine secondorder factors, and the confirmatory model with nine firstorder factors. The factor loadings in these works fall within an adequate range $(<.5)$; the factors distorted sense of time and loss of self-consciousness have presented the most problems in the factor analyses and in the internal consistency of the instrument (Jackson \& Eklund, 2002).

Of all the works on this scale, only that of Vlachopoulos, Karageorghis, and Terry (2000) found inconsistencies in the factor analysis and reliability. Thus, in their study with 1231 participants in aerobic programs, they concluded that neither the hierarchical model nor the nine first-order factor model had acceptable fit index values. As noted by these authors, this may be due to having selected more rigorous cut-off criteria, based on the proposal of $\mathrm{Hu}$ and Bentler (1999). Likewise, as noted by Byrne (2001), in scales with a large number of factors and items, as in this case, $\mathrm{Hu}$ and Bentler's proposal may be too demanding, and this should be taken into account when analyzing this work. In any case, it should be noted that some of the incoherencies found by Vlachopoulos et al. (2000) in some of the factor items of loss of self-consciousness and distorted sense of time were also indicated in previous works by Jackson and Marsh (1996) and Marsh and Jackson (1999).

Due to these minor problems, Jackson and Eklund (2002) modified some items from the original scale, creating the Flow State Scale-2 (FSS-2). Specifically, they modified 5 items from the following factors: distortion of the sense of time (2 items), loss of self-consciousness ( 1 item), sense of control (1 item), and clear feedback (1 item). We did not use this second version in our work because we began to collect data before it had been published. Moreover, it should be taken into account that the first version had adequate psychometric properties and has been considered appropriate to assess flow state in various contexts.

Lastly, with regard to the instruments that measure this construct, the Dispositional Flow Scale (DFS: Jackson, Kimiecik, Ford, \& Marsh, 1998) is also noteworthy. This instrument assesses the frequency with which a person experiences flow, or dispositional flow, with the same items as the FSS, changing only the introduction of the questionnaire, so this adaptation of the FSS can also be used for the DFS.

Some investigators have analyzed the relations between flow and motivation. Some works have found relations between task orientation (judging one's skill based on one's level of task mastery) and the tendency to experience flow (Kimiecik \& Jackson, 2002; Tipler, Marsh, Martin, Richards, \& Williams, 2004). Likewise, with regard to flow state, Jackson and Roberts (1992) found relations between task orientation, high perception of skill, and the emergence of the flow state. In a similar vein, some works have also found relations between task orientation and the appearance of diverse dimensions of flow state, such as the autothelic experience and the loss of self-consciousness (Charalambous \& Ntoumanis, 2000; Papaioannou \& Kouli, 1999), and no relations were found between ego orientation (judging one's skill by means of social comparison with others) and other dimensions of flow. However, several works carried out with Spanish sportspeople have shown positive relations between both orientations and the tendency to experience flow (SantosRosa, 2003; Moreno, Cervelló, \& González-Cutre, 2008), and between ego orientation and the dimension loss of selfconsciousness (Cervelló et al., 2007). A characteristic of these studies is that ego orientation also appears as a predictive factor of some dimensions of the flow state.

The purpose of our work is to develop a Spanish version of the Flow State Scale because, to date, no tool in our language has been developed to assess this construct. Likewise, we shall analyze its psychometric properties and we will validate it for subsequent use in research and application in Spanish-speaking populations.

\section{Method}

\section{Participants}

The sample for this study was made up of 2036 physical activity practitioners, of ages between 14 and 19 years $(M$ $=17.8, S D=2.1)$. The distribution of the sample in sport modalities was as follows: 1130 participants of recreational physical activity programs, 622 soccer players registered in federation competitions, 138 federated tennis players, 98 
swimmers, and 48 volley-ball players who participated in federation competitions. Of the 2036 participants, 1186 were male and 850 were female.

\section{Procedure}

We used random cluster sampling to select the sample (Azorín \& Sánchez-Crespo, 1986) to ensure that it correctly represented the diverse characteristics of the population (percentage of male/female, centers from the urban/rural areas, etc.). There were different sets of clusters depending on the area (sport schools, gymnasiums, sport clubs, and associations), and each one of these groups was treated independently. For this purpose, we obtained data from the sport association registers of the participants' various regions.

Before collecting the data, we agreed on a date with the monitors and sportspeople to collect the data. Likewise, we had informed the participants and their parents (in the case of minors) about the goals of the investigation and the use of the data obtained, and we obtained authorization from both (parents and sportspeople). The participants completed the flow state questionnaire just after a session of physical activity or sport, as this is considered the most appropriate time (Jackson \& Marsh, 1996).

\section{Instruments}

Flow. To assess flow, we used the Spanish adaptation of the FSS (Jackson \& Marsh, 1996). The FSS was translated, using the backward translation strategy. First, the scale was translated independently into Spanish by two groups of specialists in sport psychology who were proficient in English and Spanish. Any differences in the resulting translations were discussed by the team until they reached a final wording of the instrument. Subsequently, a different team, which was not involved in this investigation, was asked to translate the instrument back into English, to confirm whether there were any important discrepancies between the original and the translated version, and this procedure also served to revise the tool once more. As mentioned, this instrument has 36 items that assess the 9 factors that comprise the flow state. Each factor has 4 items that are rated on a 10-point Likert-type scale.

Dispositional goal orientations. To measure the students' dispositional goal orientations, we used the Spanish version of the Perception of Success Questionnaire (POSQ; Roberts, Treasure, \& Balagué, 1998). This questionnaire has 12 items: 6 measure task orientation and 6 measure ego orientation. Responses to items are rated on a Likert-type scale, ranging from 1 to 10 .

\section{Data Analysis}

The statistical program SPSS 13.0 was used to analyze the data. By means of this software, we confirmed the factor structure, correlations among items, and internal consistency. We also calculated the main descriptive statistics. We used the AMOS 5.0 software to perform the confirmatory factor analysis to determine the factor structure that best fits the data.

Before performing the analysis, we examined the skewness and kurtosis of the data of the measurement model, to confirm their normality, an essential prerequisite to perform an adequate estimation. When performing the test univariately, we obtained acceptable results, as all the parameters were between -1 and 1 . Along with the review of the histograms obtained, this indicates that the data, univariately, are normally distributed.

However, as noted by Byrne (2001), an error that is frequently made when performing confirmatory factor analysis is that the normality of the data is not taken into account multivariately. When analyzing the distribution univariately, one may obtain values that indicate the existence of a normal distribution, but this changes when the data are analyzed multivariately. This was our case, because Mardia's coefficient, with a value of 27.67, indicated the lack of multivariate normality of the data (Mardia, 1974).

There are various formulas to correct the lack of normality when performing confirmatory factor analysis: either by using an estimation method that is not affected by the anormality or by using strategies that palliate the lack of normality of the data by means of logarithmic transformation. One possibility would be to use the asymptotically distribution free method, although, as noted by Ullman (2001), this procedure is not adequate unless one has a sample of more than 2500 participants. Another possibility, the one we chose, is to use the bootstrapping procedure. This method is based on generating multiple samples from the research sample so as to produce a bootstrap distribution, and this has been verified as one of the most appropriate formulas when the rule of normality is not met and researchers wish to use the maximum likelihood estimation method (Efron, 1982).

We used following fit indexes to verify the tested models: (a) chi-square: nonsignificant values in this index (higher than .05) indicate an acceptable correspondence between the proposed model and the data; (b) chi-square/degrees of freedom: values of less than 2 indicate an excellent fit of the data, whereas values up to 5 are considered acceptable (Hu \& Bentler, 1999); (c) comparative fit index (CFI): values higher than .90 are considered acceptable (Hu \& Bentler); (d) Tucker-Lewis index (TLI): as with the CFI, it takes on values between 0 and 1, with values higher than .90 being considered acceptable; (e) root mean square error of approximation (RMSEA): this index is a measurement of the error between the model and the data. Values lower than .08 are considered acceptable (Browne \& Cudeck, 1993); (f) standardized root mean square residual (SRMR): this measures the degree to which the data fit the model and it should have a value lower than .08 to be considered acceptable (Hu \& Bentler). 
Results

\section{Factor Validity}

To verify which factor structure best fit the empirical data obtained, we performed four different analyses, as a function of the models tested in previous investigations (Jackson \& Marsh, 1996; Marsh \& Jackson, 1999; Tenenbaum et al., 1999). This yielded four models: a hierarchical model with 9 second-order factors and one first-order factor (Model A), a model with 9 first-order related factors (Model B), a model with 9 first-order unrelated factors (Model C), and a model with one sole principal factor (Model D).

An important point to be taken into account when performing confirmatory factor analysis is that there should be a minimum of 10 observations per variable of the model, according to Byrne (2001), whose proposal is adequately met in our study.

In Table 1 are shown the fit indexes of the four models tested in the confirmatory factor analysis. As can be observed, the two models that have acceptable indexes correspond to the hierarchical model with 9 second-order factors and one principal factor (Model A), and the model with 9 first-order related factors (Model B). These two models have similar indexes and therefore, we shall abide by the theoretical framework to select the most adequate.

As can be seen in the table, the significance of the chisquare means that this index is unacceptable in all the models. According to Byrne (2001), this value is very sensitive to sample size, so we had to analyze the remaining fit indexes. The rest of the goodness-of-fit indexes can be considered acceptable in the first two models, because both the CFI and the TLI have values higher than .90 , and the RMSEA and the SRMR have values lower than .080 and very near .050 in these two confirmatory analyses.

In Table 2 are displayed all the questionnaire items (in Spanish), as well as the factor loadings of each item after the analysis of Model A. As can be seen, all the items have adequate factor loadings $(>.50)$ with a statistically significant $p$-value $(p<.01)$. The value of each factor in comparison to the global factor of flow is also interesting. As can be observed, some of the factors have very high loadings, over
90. It is also noteworthy that the factors distorted sense of time, balance of action and awareness, and loss of selfconsciousness have the lowest values $(.42, .59$, and .67 , respectively).

In Table 3 are displayed the descriptive statistics of the Flow State Scale factors and the two factors of the POSQ, ego and task orientation. As can be noted, the mean scores obtained in the factors of the former scale are moderately high, with values ranging between 5.47 for distorted sense of time, and 7.28 for autothelic experience. Regarding the means of the motivational orientations, it can be seen that task orientation has a value higher than 8 , which can be considered very high, whereas ego orientation has a value of 6 .

In the last row are the values of the reliability analysis performed on each factor, with a value of Cronbach's alpha higher than .70 in all cases (Nunally, 1978). The lowest score was that of the factor distortion of sense of time.

\section{Concurrent Validity}

In order to analyze the concurrent validity of our instrument, we decided to find the relations of all the factors of the questionnaire with the motivational orientations described in the achievement goals theory (Nicholls, 1989). This theory postulates that there are two different ways to appraise competence or skill in achievement contexts: One way consists of judging skill by means of social comparison with others, so one feels successful when one displays more skill than others (ego orientation), and the other is a judgment of skill based on the level of task mastery, in this case, ignoring social comparison as a source of competence (task orientation).

Previous works that have analyzed these relations in samples of American and European practitioners have found that task orientation is related to some dimensions of flow (Jackson \& Roberts, 1992; Papaioannou \& Kouli, 1999), whereas in samples of Spanish sportspeople, ego orientation has also been shown to predict flow (Cervelló et al., 2007). Our hypothesis is the same as in previous studies: Both task orientation and ego orientation are positively related to the dimensions of flow.

Table 1

Fit Index Values for the four Models tested for the Flow State Scale

\begin{tabular}{lcccccccc}
\hline Models & $\chi^{2}$ & $d f$ & $p$ & $\chi^{2} / d f$ & CFI & TLI & RMSEA & SRMR \\
\hline Model A & 4253.746 & 585 & .000 & 7.271 & .91 & .90 & .054 & .051 \\
Model B & 3763.006 & 558 & .000 & 6.744 & .92 & .91 & .052 \\
Model C & 14974.462 & 594 & .000 & 25.210 & .61 & .60 & .048 \\
Model D & 9398.592 & 594 & .000 & 15.823 & .76 & .75 & .095 & .069 \\
\hline
\end{tabular}

Note. $\mathrm{A}=$ Hierarchical model with one principal factor and nine second-order factors; $\mathrm{B}=$ model with nine first-order related factors; $\mathrm{C}$ $=$ model with nine first-order unrelated factors; $\mathrm{D}=$ model with one sole factor. $\mathrm{CFI}=$ comparative fit index; TLI = Tucker-Lewis Index; RMSEA $=$ Root mean square error of approximation; SRMR = standardized root mean square residual. 
Table 2

Factor Loadings of the Confirmatory Factor Analysis of the SpanishVersion of the FlowState Scale used in Model A

Item nr./ Item A-C A-A C-G C-F C-T S-C L-S D-T A-E

1. Sabía que mi capacidad me permitiría hacer frente al desafío que se me planteaba.

.658

10. Mi habilidad estaba al mismo nivel de lo que me exigía la situación.

.646

19. Sentía que era lo suficientemente bueno para hacer frente a la dificultad de la situación

.735

28. Las dificultades y mis habilidades para superarlas, estaban a un mismo nivel.

2. Hice los gestos correctos sin pensar, de forma automática.

11. Parecía que las cosas estaban sucediendo automáticamente.

20. Ejecutaba automáticamente.

29. Hacía las cosas espontánea y automáticamente. .757

3. Conocía claramente lo que quería hacer.

12. Estaba seguro de lo que quería hacer.

21. Sabía lo que quería conseguir.

30. Mis objetivos estaban claramente definidos.

4. Tenía realmente claro que lo estaba haciendo bien.

13. Sabía lo bien que lo estaba haciendo.

22. Tenía buenos pensamientos acerca de lo bien que lo estaba haciendo mientras estaba practicando.

31. Estaba seguro de que en ese momento, lo estaba haciendo muy bien.

5. Mi atención estaba completamente centrada en lo que estaba haciendo.

14. No me costaba mantener mi mente en lo que estaba sucediendo.

23. Tenía una total concentración.

32. Estaba totalmente centrado en lo que estaba haciendo.

6. Sentía un control total de lo que estaba haciendo.

15. Sentía que podía controlar lo que estaba haciendo.

24. Tenía un sentimiento de control total.

33. Sentía un control total de mi cuerpo.

7. No me importaba lo que los otros podían haber estado pensando de mí.

16. No estaba preocupado por mi ejecución

25. No estaba preocupado por la imagen que daba a los demás.

34. No me preocupaba lo que otros pudieran estar pensando de mí.

8. El tiempo parecía diferente a otras veces (ni lento, ni rápido)

17. El paso del tiempo parecía ser diferente al normal.

26. Sentía como si el tiempo se parase mientras estaba practicando.

35. A veces parecía que las cosas estaban sucediendo como a cámara lenta.

9. Realmente me divertía lo que estaba haciendo

18. Me gustaba lo que estaba experimentando en ese momento y me gustaría sentirlo de nuevo.

27. La experiencia me dejó un buen sabor de boca (buena impresión).

36. Encontré la experiencia muy valiosa y reconfortante.

Note. $\mathrm{A}-\mathrm{C}=$ Balance between ability level and challenge, $\mathrm{A}-\mathrm{A}=$ Merging of action and awareness, $\mathrm{C}-\mathrm{G}=\mathrm{Clear}$ goals, $\mathrm{C}-\mathrm{F}=\mathrm{Clear}$, direct feedback, C-T = Concentration on task, S-C = Sense of control, L-S = Loss of self-consciousness, D-T = Distorted sense of time, $\mathrm{A}-\mathrm{E}=$ Autothelic experience.

[Translator's note: the scale items have not been translated into English because this is the Spanish version of a scale originally published in English.] 
Table 3

Descriptive Statistics and Internal Consistency of the Flow State Scale and the Perception of Success Questionnaire

\begin{tabular}{|c|c|c|c|c|c|}
\hline Dimensions & $M$ & $S D$ & Minimum & Maximum & $\alpha$ \\
\hline Balance between ability level / challenge & 6.56 & 6.56 & 6.56 & 6.56 & 6.56 \\
\hline Merging of action / awareness & 5.66 & 5.66 & 5.66 & 5.66 & 5.66 \\
\hline Clear goals & 7.20 & 7.20 & 7.20 & 7.20 & 7.20 \\
\hline Concentration on task & 6.61 & 6.61 & 6.61 & 6.61 & 6.61 \\
\hline Clear direct feedback & 7.20 & 7.20 & 7.20 & 7.20 & 7.20 \\
\hline Sense of control & 6.92 & 6.92 & 6.92 & 6.92 & 6.92 \\
\hline Loss self-consciousness & 6.38 & 6.38 & 6.38 & 6.38 & 6.38 \\
\hline Distorted sense of time & 5.47 & 5.47 & 5.47 & 5.47 & 5.47 \\
\hline Autothelic experience & 7.28 & 7.28 & 7.28 & 7.28 & 7.28 \\
\hline Flow & 7.28 & 7.28 & 7.28 & 7.28 & 7.28 \\
\hline Ego & 6.07 & 6.07 & 6.07 & 6.07 & 6.07 \\
\hline Task & 8.43 & 8.43 & 8.43 & 8.43 & 8.43 \\
\hline
\end{tabular}

Table 4

Correlations between the Principal Factor, the Second-Order Factors and the Motivational Orientations

\begin{tabular}{|c|c|c|c|c|c|c|c|c|c|c|c|}
\hline & $\mathrm{A}-\mathrm{C}$ & A-A & $\mathrm{C}-\mathrm{G}$ & $\mathrm{C}-\mathrm{F}$ & $\mathrm{C}-\mathrm{T}$ & $\mathrm{S}-\mathrm{C}$ & L-S & D-T & A-E & Flow & Ego \\
\hline Balance between ability level / challenge & - & & & & & & & & & & \\
\hline Merging of action / awareness & $.492 * *$ & - & & & & & & & & & \\
\hline Clear goals & $.657 * *$ & $.428 * *$ & - & & & & & & & & \\
\hline Concentration on task & $.677 * *$ & $.460 * *$ & $.648 * *$ & - & & & & & & & \\
\hline Clear direct feedback & $.547 * *$ & $.445^{* *}$ & $.604 * *$ & $.577 * *$ & - & & & & & & \\
\hline Sense of control & $.672 * *$ & $.427 * *$ & $.701 * *$ & $.748 * *$ & $.726^{* *}$ & - & & & & & \\
\hline Loss self-consciousness & $.451 * *$ & $.400 * *$ & $.403 * *$ & $.445^{* *}$ & $.443^{* *}$ & $.411 * *$ & - & & & & \\
\hline Distorted sense of time & $.295^{* *}$ & $.358^{* *}$ & $.128 * *$ & $.180 * *$ & $.372 * *$ & $.309 * *$ & $.234 * *$ & - & & & \\
\hline Autothelic experience & $.551 * *$ & $.268^{* *}$ & $.552 * *$ & $.519 * *$ & $.598 * *$ & $.564 * *$ & $.372 * *$ & $.243^{* *}$ & - & & \\
\hline Flow & $.786^{* *}$ & $.599 * *$ & $.759 * *$ & $.797 * *$ & $.745^{* *}$ & $.832 * *$ & $.599 * *$ & $.468 * *$ & $.715^{* *}$ & - & \\
\hline Ego & $.247 * *$ & $.116^{* *}$ & $.183 * *$ & $.231 * *$ & $.165^{* *}$ & $.190 * *$ & $.117 * *$ & .034 & .023 & $.213 * *$ & - \\
\hline Task & $.358 * *$ & $.366^{* *}$ & $.254 * *$ & $.259 * *$ & $.239 * *$ & $.256 * *$ & $.279 * *$ & $.223 * *$ & $.210 * *$ & $.219 * *$ & .038 \\
\hline
\end{tabular}

Note. A-C $=$ Balance between ability level and challenge, A-A = Merging of action and awareness, $\mathrm{C}-\mathrm{G}=\mathrm{Clear}$ goals, $\mathrm{C}-\mathrm{F}=\mathrm{Clear}$, direct feedback, C-T = Concentration on task, $\mathrm{S}-\mathrm{C}=$ Sense of control, $\mathrm{L}-\mathrm{S}=$ Loss of self-consciousness, D-T $=$ Distorted sense of time, $\mathrm{A}-\mathrm{E}=$ Autothelic experience.

$* p<.05 . * * p<.01$.

In Table 4 are displayed the results obtained after calculating bivariate correlations with the diverse factors of flow, the principal factor, and the two motivational orientations studied, showing that all the factors correlate significantly with the motivational orientations, except for distorted sense of time and autothelic experience in relation to ego orientation.

\section{Discussion}

As commented throughout this work, the variable flow may be very important in the cognitive processes that affect sportspeople, both when seeking peak performance and in personal satisfaction and well-being when practicing sports.
However, until a few years ago, there was no instrument that could quantitatively measure each one of the dimensions that comprise this variable. Therefore, we consider that the results obtained in the process of validation of the Spanish version of the instrument are important and interesting for its application in future research and interventions with sportspeople.

Regarding the analysis of the results obtained, we would like to emphasize the optimal reliability values obtained, in which Cronbach's alpha reached values of over .70, and in many cases over .80. This indicates that the Spanish version of the FSS is highly reliable and consistent in the measurement of its factors. Similar results were found in the adaptations of this instrument to other languages (Doganis et al., 2000; Stavrou \& Zervas, 2004). 
We note that the element distorted sense of time obtained the lowest value. This was also observed in other investigations (Jackson \& Marsh, 1996; Marsh \& Jackson, 1999; Vlachopoulous et al., 2000), and sometimes this value did not even exceed .70. Although this was not our case, we consider this may be due to the different ways of perceiving this dimension depending on the sport modality practiced. For example, it is logical that, in order to achieve flow, a long-distance swimmer would need to sense that time passes much quicker than it really does, that is, that the minutes go by as if they were seconds. This way, the trial would seem shorter to the sportspeople, thus decreasing their sensation of fatigue. However, sportspeople who practice a short sport or one that requires very fast movements to be effective would need to sense that time goes by much slower than it really does. For example, a soccer-player who receives the ball in the opponent's area will have a few milliseconds to resolve the move successfully. If, during that time, the player feels that everything is moving in slow-motion, much slower than in reality, it will certainly be easier to perform the action effectively. This explanation was also postulated by Jackson and Eklund (2002) when stating that the items used to measure this factor focused particularly on indicating that time goes by slower than normal when, as mentioned, this does not always happen. Taking into account that in our sample there were many sportspeople from different modalities, we performed an analysis of variance and found that there were significant differences in this factor between swimmers and the remaining sportspeople, which reconfirms the lower reliability of this factor in the measurement instrument. Moreover, when analyzing the reliability after eliminating the swimmers and tennis players from the sample, the alpha value rose to .76 .

Regarding the results obtained when testing the diverse models of confirmatory factor analysis, only the model with the hierarchical structure, which had one global factor and nine second-order factors (Model A), and the model with nine first-order related factors (Model B) had acceptable fit. Both models obtain similar values in the fit indexes, so that either one of them is valid. However, if we abide by the theoretical framework, the hierarchical model is more appropriate, because the theory indicates that the factors that make up the instrument are the elements that constitute the state of flow (Jackson \& Marsh, 1996).

Jackson and Eklund (2002) and Marsh and Jackson (1999) obtained similar results in the works carried out to test the psychometric characteristics of the FSS. In these works, both the hierarchical model and the model with nine first-order factors fit the empirical data. Despite this, as noted by Marsh and Jackson, the hierarchical model is more appropriate because, besides matching the theoretical framework better, it is much more parsimonious, and has more degrees of freedom when performing the calculations. Thus, by means of this confirmatory model, we can determine the importance of each one of the factors in the global flow state, which can contribute valuable information about their influence on the achievement of an optimal psychological state. With regard to this issue, the two factors that showed inconsistency in other works, loss of selfconsciousness and distorted sense of time, also had lower factor loadings in the confirmatory factor analysis (Jackson \& Marsh, 1996; Vlachopoulos et al., 2000).

Regarding the results obtained when relating the diverse factors of flow with the participants' motivational orientations, both task orientation and ego orientation correlated positively with all the elements of the flow state and with its global factor. All these correlations were significant except for those between ego orientation and the factors distorted sense of time and autothelic experience. These results are not in accordance with those obtained by Jackson, Kimiecik, Ford, and Marsh (1998), because these authors did not obtain any significant relation between motivational orientations and the flow factors, although the procedure and the sample were different from those used in this study. A notable result is the low absolute value of the correlations found between the dispositional orientations and the dimensions of flow. Although this could be expected for ego orientation, it was surprising in the case of task orientation. A possible explanation could be related to the heterogeneity of the sample used in the study, in which sportspeople with competitive goals and people involved in recreational sports both participated, and therefore, the motivational orientations could have very heterogeneous values.

Despite this, in our results, both orientations correlate positively and significantly with the factors of flow. This confirms the proposal of Stein, Kimiecik, Daniels, and Jackson (1995), who, in a study carried out with a sample of competitive and recreational sportspeople, concluded that in both of them, flow could appear and therefore, both the participants who are motivationally ego oriented and those who are task oriented could achieve an optimal psychological state to practice sport. Likewise, in a study carried out with soccer players (García Calvo, Cervelló, Jiménez, Iglesias, \& Santos-Rosa, 2005), similar results were obtained, with flow correlating with both types of orientations. As noted in this work, this result may be due to the mediation of perceived skill, because ego orientation is considered adaptive and with similar behavior patterns as task orientation if it appears together with high perceived skill.

To conclude, we would like to point out that, despite the adequate values found in the analysis of adaptation of the Flow State Scale to Spanish, we consider that the items of the factors distorted sense of time and loss of selfconsciousness should be revised in future studies to optimize their levels of internal consistency and validity.

Lastly, we wish to emphasize that the importance of obtaining psychometrically valid instruments has been noted in many works (Cox et al., 2006; Remor, 2006), and therefore, investigations that can contribute such knowledge are essential 
for the adequate development of studies. Moreover, according to Csikszentmihalyi (1990, 1997), flow appears in all areas of life, and is necessary to experience a more complete life and it is closely related to satisfaction with one's activities. Therefore, we consider that the adaptation of this tool to Spanish and its validation can contribute a very fruitful line of research and work, because this instrument can be modified for use in many areas of psychology.

\section{References}

Azorín, F., \& Sánchez-Crespo, J.L. (1986). Métodos y aplicaciones del muestreo. Madrid: Alianza Editorial.

Browne, M.W., \& Cudeck, R. (1993). Alternative ways of assessing model fit. In K.A. Bollen \& J.S. Long (Eds.), Testing structural equation models (pp. 136-162). Newbury Park, CA: Sage.

Byrne, B.M. (2001). Structural equation modeling with AMOS: Basic concepts, applications, and programming. Mahwah, NJ: Erlbaum.

Cervelló, E., Santos-Rosa, F.J., Jiménez, R., García Calvo, T., \& Iglesias, D. (2007). Young tennis players' competitive task involvement and performance: The role of goal orientations, contextual motivational climate, and coach-initiated motivational climate. Journal of Applied Sport Psychology, 19, 304-321

Charalambous, M., \& Ntoumanis, N. (2000). Goal orientations and

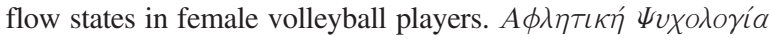
(Sport Psychology), 11, 55-76.

Craft, L.L., Magyar, T.M., Becker, B.J., \& Feltz, D.L. (2003). The relationship between the Competitive State Anxiety Inventory2 and sport performance: A meta-analysis. Journal of Sport and Exercise Psychology, 25, 44-65.

Cox, T., Oliver, A., Rial-González, E., Tomás, J. M., Griffiths, A., \& Thompson, L. (2006). The development of a Spanish language version of the Worn Out Scale of the General WellBeing Questionnaire (GWBQ). The Spanish Journal of Psychology, 9, 94-102.

Csikszentmihalyi, M. (1975). Beyond boredom and anxiety. San Francisco: Jossey-Bass.

Csikszentmihalyi, M. (1990). Flow: The psychology of optimal experience. New York: Harper \& Row.

Csikszentmihalyi, M. (1997). Finding flow: The psychology of engagement with everyday life. New York: Harper Perennial.

Csikszentmihalyi, M., \& Csikszentmihalyi, I. S. (1988). Optimal experience: Psychological studies of flow in consciousness. Cambridge, UK: Cambridge University Press.

Csikszentmihalyi, M., \& Larson, R. (1987). Validity and reliability of the experience-sampling method. Journal of Nervous and Mental Disease, 175, 526-536.

Csikszentmihalyi, M., \& LeFevre, J. (1989). Optimal experience in work and leisure. Journal of Personality and Social Psychology, 56, 815-822.

Doganis, G., Iosifidou, P., \& Vlachopoulos, S. (2000). Factor structure and internal consistency of the Greek version of the Flow State Scale. Perceptual \& Motor Skills, 91, 1231-1240.
Efron, B. (1982). The jackknife, the bootstrap and other resampling plans. Philadelphia: SIAM.

Ellis, G., D., Voelkl, J. E., \& Morris, C. (1994). Measurement and analysis issues with explanation of variance in daily experience using the flow model. Journal of Leisure Research, 26, 337356.

García Calvo, T., Cervelló, E.M., Jimenez, R., Iglesias, D., \& Santos-Rosa, F.J. (2005). La implicación motivacional de jugadores jóvenes de fútbol y su relación con el estado de fluidez y la satisfacción en competición. Revista de Psicología del Deporte, 14, 21-42.

Ghani, J., \& Deshpande, S. (1994). Task characteristics and the experience of optimal flow in human-computer interaction, The Journal of Psychology, 128, 381-391.

Hu, L., \& Bentler, P.M. (1999). Cut off criteria for fit indexes in covariance structure analysis: Conventional criteria versus new alternatives. Structural Equation Modeling, 6, 1-55.

Jackson, S. A. (1993). Elite athletes in flow: The psychology of optimal sport experience. Dissertation Abstracts International, $54,124$.

Jackson, S. A. (1996). Toward a conceptual understanding of the flow experience in elite athletes. Research Quarterly for Exercise and Sport, 1, 67-76.

Jackson, S.A., \& Csikszentmihalyi, M. (1999). Flow in sports: The keys to optimal experiences and performances. Champaign, IL: Human Kinetics.

Jackson, S. A., \& Eklund, R. C. (2002). Assessing flow in physical activity: The Flow State Scale-2 and Dispositional Flow Scale2. Journal of Sport \& Exercise Psychology, 24, 133-150.

Jackson, S.A., Kimiecik, J., Ford, S., \& Marsh, H.W. (1998). Psychological correlates of flow in sport. Journal of Sport \& Exercise Psychology, 20, 358-378.

Jackson, S. A., \& Marsh, H. (1996). Development and validation of a scale to measure optimal experience: The Flow State Scale. Journal of Sport \& Exercise Psychology, 18, 17-35.

Jackson, S. A., \& Roberts, G. C. (1992). Positive performance states of athletes: Toward a conceptual understanding of peak performance. The Sport Psychologist, 6, 156-171.

Kimiecik, J. C., \& Jackson, S. A. (2002). Optimal experience in sport: A flow perspective. In T. Horn (Ed.), Advances in sport psychology (pp. 501-527). Champaign IL: Human Kinetics.

Kimiecik, J. C., \& Stein, G. L. (1992). Examining flow experiences in sport contexts: Conceptual issues and methodological concerns. Journal of Applied Sport Psychology, 4, 144-160.

Mardia, K.V. (1974). Applications of some measures of multivariate skewness and kurtosis in testing normality and robustness studies. Sankhya, 36, 115-128

Marsh, H. W., \& Jackson, S. A. (1999). Flow experience in sport: Construct validation of multidimensional, hierarchical state and trait responses. Structural Equation Modeling, 6, 343371.

Moreno, J.A., Cervelló, E., \& González-Cutre, D. (2008). Relationships among goal orientations, motivational climate and flow in adolescent athletes: Differences by gender. Spanish Journal of Psychology, 11, 181-191. 
Mundell, C. E. (2000). The role of perceived skill, perceived challenge, and flow in the experience of positive and negative affect. Dissertation Abstracts International: Section B: The Sciences y Engineering, 61, 2802.

Nicholls, J. G. (1989). The competitive ethos and democratic education. Cambridge, MA: Harvard University Press.

Nunally, J.C. (1978). Psychometric theory. New York: McGrawHill.

Papaioannou, A., \& Kouli, O. (1999). The effect of task structure, perceived motivational climate and goal orientation on students' task involvement and anxiety. Journal of Applied Sport Psychology, 11, 51-71.

Privette, G., \& Bundrick, C. M. (1987). Measurement of experience: Construct and content validity of the Experience Questionnaire. Perceptual \& Motor Skills, 65, 315-332.

Remor, E. (2006). Psychometric properties of a European Spanish version of the Perceived Stress Scale (PSS). The Spanish Journal of Psychology, 9, 86-93.

Roberts, G. C. (2001). Understanding the dynamics of motivation in physical activity: The influence of achievement goals and motivational processes. In G. C. Roberts (Ed.), Advances in motivation in sport and exercise (pp. 1-50). Champaign: IL: Human Kinetics.

Roberts, G.C., Treasure, D.C., \& Balagué, G. (1998). Achievement goals in sport: The development and validation of the Perception of Success Questionnaire. Journal of Sport Sciences, 16, 337 - 347.

Ryan, R. M., \& Deci, E. L. (2002). Overview of self-determination theory: An organismic-dialectical perspective. In E. L. Deci \& R. M. Ryan (Eds.), Handbook of self-determination research. (pp. 3-33). Rochester, NY: University of Rochester Press.

Santos-Rosa, F. J. (2003). Motivación, ansiedad y flow en jóvenes tenistas. Unpublished doctoral dissertation. Cáceres (Spain): Universidad de Extremadura.

Smith, R.E., Smoll, F.L., Cumming, S.P., \& Grossbard, J.R. (2006). Measurement of multidimensional sport performance anxiety in children and adults: The Sport Anxiety Scale-2. Journal of Sport and Exercise Psychology, 28, 479-501.

Stavrou, N. A., \& Zervas, Y. (2004). Confirmatory factor analysis of the Flow State Scale in sports., International Journal of Sport and Exercise Psychology, 2, 161-181.

Stein, G. L., Kimiecik, J. C., Daniels, J., \& Jackson, S. A. (1995). Psychological antecedents of flow in recreational sport. Personality \& Social Psychology Bulletin, 21, 125-135.

Tenenbaum, G., Fogarty, G. J., \& Jackson, S. A. (1999). The flow experience: A Rasch analysis of Jackson's Flow State Scale. Journal of Outcome Measurement, 3, 278-294.

Tipler, D., Marsh, H. W., Martin, A. J., Richards, G. E., \& Williams, M. R. (2004). An investigation into the relationship between physical activity motivation, flow, physical self-concept and activity levels in adolescence. In H. W. Marsh, J. Baumert, G. E. Richards, \& U. Trautwein (Eds.), Self-concept, motivation an identity: Where to from here? (pp. 421-485). Proceedings of the SELF Research Biennial International Conference, Max Planck Institute Berlin, Germany.

Trevino, L. K., \& Webster, J. (1992). Flow in computer-mediated communication: Electronic mail and voice mail evaluation and impacts. Communication Research, 19, 539-573.

Ullman, J. B. (2001). Structural equation modeling. In B.G. Tabachnick \& L.S. Fidell (Eds.), Using multivariate statistics (4 ${ }^{\text {th }}$ ed., pp. 653-771). Needham Heights, MA: Allyn \& Bacon.

Vlachopoulos, S. P., Karageorghis, C. I., \& Terry, P. C. (2000). Hierarchical confirmatory factor analysis of the Flow State Scale in exercise. Journal of Sports Sciences, 18, 815-823.

Webster, J., Trevino, L. K., \& Ryan, L. (1993). The dimensionality and correlates of flow in human computer interactions. Computers in Human Behavior, 9, 411-426.

Received May, 28, 2007 Revision received January 23, 2008 Accepted April 5, 2008 